\title{
Diamondiferous kimberlite from Garnet Lake, West Greenland II: diamonds and the mantle sample
}

\author{
M.T. Hutchison and D. Frei \\ Geological Survey of Denmark and Greenland, Øster Voldgade 10, DK-1350 Copenhagen K, \\ Denmark (mth@trigon-gs.com)
}

Kimberlite and kimberlite-affinity rocks occur as shallow ( 24 degree), north-east (True) dipping sheets at Garnet Lake, Sarfartoq, West Greenland (Hutchison, 2005). The location of Garnet Lake and discussion of the mineralogy, petrology and physical characteristics of the Garnet Lake kimberlite are presented in this volume in Hutchison (2008, this volume), whilst the mantle sample incorporated as xenoliths and xenocrysts is discussed herein.

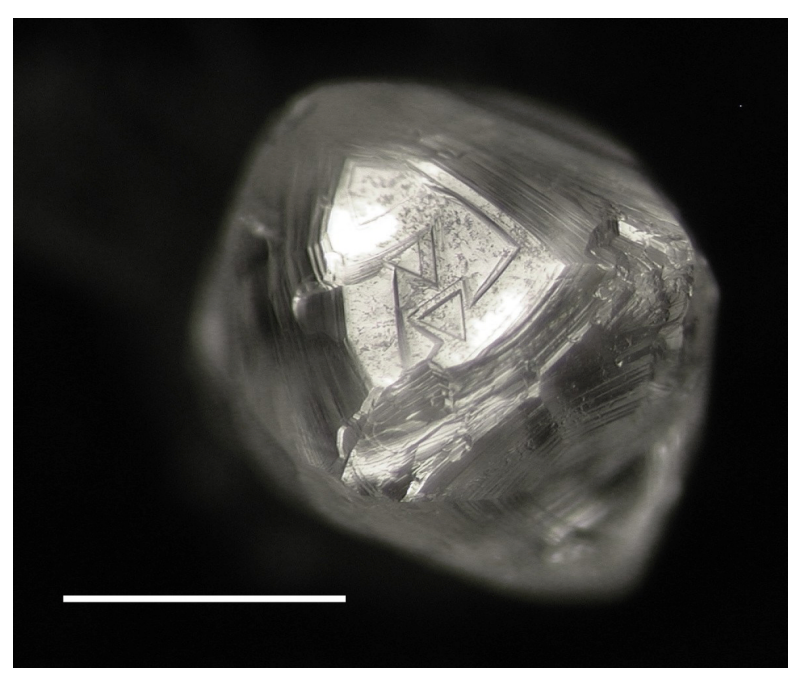

Fig. 1 Diamond MHG9-13_1

Showing negative trigon etching; scale bar $1 \mathrm{~mm}$

In the Garnet Lake area, some outcropping rocks contain a high abundance of visually identifiable mantle material. Of particular note is the Silly Kimberlite which occurs as a clast-supported 'xenolithite' dominantly comprising dunite and garnet lherzolites, however the diamond contents acquired from such rocks are low (Hutchison, 2005). On the other hand the max. 4 metre thick Garnet Lake socalled main sheet (m.s.) targeted due to its high diamond abundance, is characterised by a marked paucity of in-tact mantle xenoliths compared to nearby sheets. Xenoliths when they rarely occur in the main sheet are typically harzburgites with other types as described below. However much more commonly, the visibly identifiable mantle material appears in the form of discrete red pyrope garnet xenocrysts (Hutchison, 2005) up to $5 \mathrm{~mm}$ and typically with black kelphytised rims. In addition to xenolith material, heavy mineral separation subsequent to crushing of surface and drill core samples yields an abundance of mantleassociation minerals including eclogitic and peridotitic garnet, picro-ilmenites, Cr-spinels, $\mathrm{Cr}$-diopsides and olivine, i.e. so-called kimberlite indicator minerals (KIMs). Recent bulk sampling has also revealed diamond macrocrysts visible within kimberlite (pers. comm. Hudson Resources Inc., 2008). Finally it is important to note that size, morphology and composition of olivine crysts in Garnet Lake area samples suggest that the majority of olivine crysts are in fact xenocrysts and are out of equilibrium with the final kimberlitic melt, consistent with the arguments of Nielsen and Sand (2008). This observation has important implications for the petrological classification of the Garnet Lake and other West Greenland rocks however it also demonstrates that the Garnet Lake m.s., although poor in xenoliths, does still contain significant quantities of mantle material.

Here we present physical and chemical characteristics of discrete mantle minerals, including diamond and also xenoliths from the Garnet Lake m.s. and associated geothermobarometric and diamond formation temperature / mantle residence calculations. These data and calculations are employed to gain insights into the ambient mantle conditions and conditions for diamond growth during and immediately prior to kimberlite emplacement.

\section{Methodologies}

Major and minor element compositions of mantle phases were determined from mineral separates mounted in epoxy and from polished thin sections using the University of Copenhagen's JEOL JXA-8200 electron microprobe. Standardisation was achieved against natural and synthetic standards. Trace element compositions were determined using the laser ICPMS of the Geological Survey of Denmark and Greenland. Nitrogen concentrations in diamond were determined using Thermo-Nicolet Fourier transform infra-red (FTIR) spectrometry units of the Universities of British Columbia and Alberta. Deconvolution of spectra was carried out using the methods of Boyd et al. (1994, 1995).

\footnotetext{
Diamond characteristics and composition

Typically diamonds are colourless and irregular or octahedral in morphology (e.g. Fig. 1). Nitrogen concentrations for 120 stones analysed by FTIR spectrometry are high (average $1031 \mathrm{ppm} \mathrm{N}$ ) and yet at the same time nitrogen is not strongly aggregated (average of $33.7 \% \mathrm{IaB}$ aggregated).
} 
Data show an almost Gaussian distribution of diamond nitrogen concentration (Fig. 2a) however two populations in terms of nitrogen aggregation are apparent with a sharp peak around 20\% IaB superimposed on a broad peak over $50 \%$ IaB described by the population as a whole (Fig. 2b). No correlation is apparent between stone size and nitrogen concentration or aggregation.
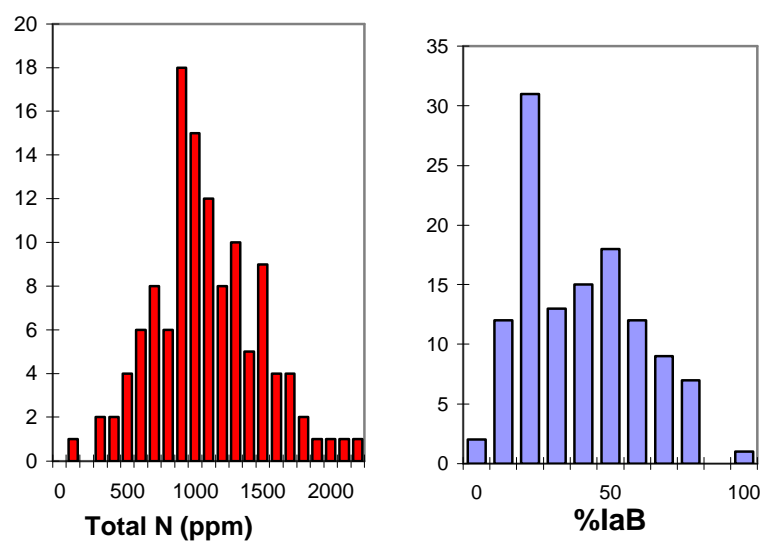

a

b

Fig. 2. Number of stones in relation to: a:- total Nitrogen concentration (ppm); b:- \% aggregation to Type IaB

Such a combination of nitrogen-abundant yet poorly aggregated nitrogen clusters is uncommon and necessitates either a short mantle residence time, cool mantle residence temperature or more likely a combination of both. Assuming a mantle residence temperature of $1258^{\circ} \mathrm{C}$ (which is supported by geothermobarometry as described in the following) and following the methodology of Taylor et al. (1990) and constants from Mendelssohn and Milledge (1995), 46\% of diamonds are calculated to have formed within the 5 m.y. immediately before kimberlite emplacement. However the broad peak in nitrogen aggregation around $50 \% \mathrm{IaB}$, assuming the same residence temperature, supports an additional diamond forming event concentrated between 15-25 m.y. before emplacement. Finally, the most aggregated diamonds suggest that at this same temperature, the oldest diamonds started to form approx. 56 m.y. before emplacement. The age of the Garnet Lake kimberlite senso stricto is $568 \pm 11 \mathrm{Ma}$ (Frei et al., 2008, this volume) which is contemporaneous with revised age determinations of the emplacement of the Sarfartoq carbonatite complex lying $21 \mathrm{~km}$ distant (Secher et al., 2008). Garnet Lake kimberlitic rocks also have a geochemical affinity with carbonatite (Hutchison, 2005) and field observations suggest a style of emplacement where the Garnet Lake m.s. appears to comprise part of a cone-sheet complex of intrusions centred at the location of the carbonatite complex (pers. comm. Larsen, L.M., GEUS, 2006). Combining emplacement age with diamond residence times gives a peak diamond formation at 583 - 593 Ma and a commencement of diamond formation around $624 \mathrm{Ma}$. Given the significant error that temperature assumptions apply to these ages, they cannot be considered to be absolute. However data demonstrate that the chemical conditions necessary for formation of diamond increased to a point where carbonatite and associated kimberlitic magmatism occurred. Although it is not suggested that the diamonds formed within kimberlite, it is proposed that mantle re-fertilisation may have triggered diamond growth as well as carbonatite and associated kimberlite and ultra-mafic lamprophyre formation which acted as carriers for the diamonds and other mantle material.

\section{Heavy Mineral Separates}

Heavy mineral separate compositions are described in Hutchison (2005). Garnet Lake m.s. garnets commonly lie within the G10D field of Grütter et al. (2004), although G9 garnets and eclogitic garnets are also common. Notably, some G4D garnets are very Na-rich, exhibiting up to $0.28 \mathrm{wt} \% \mathrm{Na}_{2} \mathrm{O}$. Picro-ilmenites contain up to $14.4 \mathrm{wt} \% \mathrm{MgO}$ and are occasionally also $\mathrm{Cr}_{2} \mathrm{O}_{3}$-rich (up to $5.5 \mathrm{wt} \% \quad \mathrm{Cr}_{2} \mathrm{O}_{3}$ ). According to accepted compositional criteria, in short, most KIM compositions lie within the diamond stability field (Hutchison, 2005). Although present in some xenoliths, as described below, chromite is rare in Garnet Lake m.s. mineral separates presumably due to their small size appearing as they do in thin section in reaction rims around garnets.

Concentrations of trace elements have been determined for heavy mineral separates of garnet, olivine and $\mathrm{Cr}$ diopside with results for Rare Earth Elements (REE) in peridotitic garnets being presented in Fig. 3 .

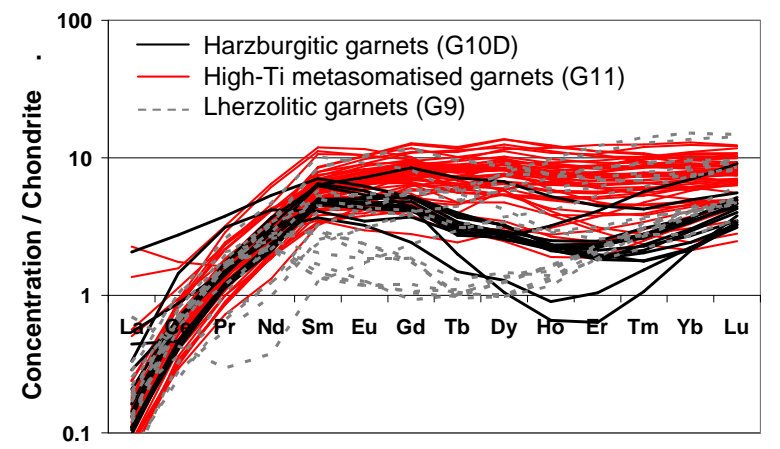

Fig. 3. REE concentrations in peridotitic garnet mineral separates from Garnet Lake m.s., normalised to C1 chondrite composition (McDonough and Sun, 1995)

Lherzolitic garnets and in particular the G11 high-Ti metasomatised garnets are comparable in composition to those from Birim, Ghana (Stachel and Harris, 1997) and following their argument reflects a fully refertilised garnet lherzolite component in the mantle. In this case, rather than metasomatism being detrimental to diamond growth, rather the process appears to have been conducive. REE partition coefficients of Fujimaki et al. (1987) have been applied to typical harzburgitic and lherzolitic garnets from Garnet Lake m.s. mineral separates. Melt calculated from lherzolitic garnets corresponds better with melt from $\mathrm{cpx}$ separated than 
melt based on harzburgitic garnets particularly over the heavy REE. Hence, in the absence of xenolith samples where equilibration between associated mineral phases can be more closely determined, trace element studies can provide a quality control method to establish which heavy mineral phases are likely to be in equilibrium as a prelude to application of geothermobarometry to mineral separates.

\section{Mantle Xenoliths}

Xenoliths when they rarely occur in the main sheet are typically harzburgites with occasional garnet dunites and garnet lherzolites. This is consistent with the composition and abundance of indicator minerals separated from crushed core and hand samples (Hutchison, 2005) although G10 garnets are more common in the disaggregated mantle material than in the complete xenoliths. A couple of equigranular picroilmenite-rich $(50 \%$ by volume) xenoliths containing garnet and some minor opx have also been identified. Here, garnets have eclogitic G4 and G4D compositions (after Grütter et al., 2004) occasionally with magnetite inclusions. Ilmenite contains up to $14.6 \mathrm{wt} \% \mathrm{MgO}$ whilst $\mathrm{Ni}$ is low $(<0.2 \mathrm{wt} \% \mathrm{NiO})$ and opx has a range of $\mathrm{Mg} \#$ between 0.88-0.93.

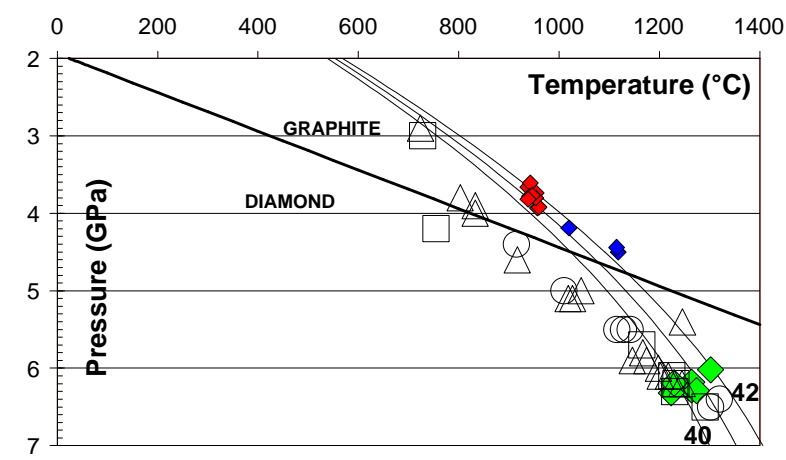

Fig. 4. Pressure / temperature data for western Greenland mantle xenoliths.

Green diamonds :- Garnet Lake main sheet; Open symbols :West Greenland (circles: Maniitsoq area, Sand et al. (2008, this volume), diamonds: Garnet Lake area, Sand et al. (2008, this volume); squares: Garnet Lake area, Bizzarro and Stevenson (2003)); Small coloured symbols :- S.W. Greenland (red: Pyramidefjeld, Nielsen et al. (2008 this volume), blue: Midternæs, Nielsen et al. (2008, this volume)); Diamond / graphite phase boundary after Kennedy and Kennedy (1976); 40 and 42 (labelled) and $41 \mathrm{mWm}^{-2}$ geotherms after Chapman and Pollack (1977).

\section{Thermobarometry}

Five garnet lherzolites were selected from core and hand samples from the Garnet Lake main sheet and prepared for thermobarometry. Garnet, olivine, clinopyroxene and orthopyroxene cores were selected for analysis using criteria based on proximity and morphology to ensure a maximum likelihood of mutual equilibrium. Pressure and temperature estimates were calculated using an iterative approach combining the methods of thermometry of McGregor (1974) and barometry of Brey and Köhler (1990). This combined geothermobarometer has been determined after vigorous testing by Sand (2007) to yield results most likely to be closest to true ambient conditions for similar West Greenland xenoliths. Results for Garnet Lake samples are shown in Fig. 4 in comparison with data from xenoliths hosted in West Greenland kimberlitic rocks of similar, likely Cambrian age from within a $150 \mathrm{~km}$ radius of Garnet Lake (Bizzarro and Stevenson, 2003 and Sand et al., 2008, this volume) and from likely Jurassic mantle (Nielsen et al., 2008, this volume).

Fig. 4 demonstrates that at a maximum of $6.29 \mathrm{GPa}$, $1274^{\circ} \mathrm{C}$, the Garnet Lake xenoliths recovered from the main diamondiferous sheet were sourced from well within the diamond stability field, coincident with a relatively cool, $40-41 \mathrm{mWm}^{-2}$ geotherm and are some of the deepest measured mantle rocks in West Greenland at up to $199 \mathrm{~km}$. With regard to source depth, Garnet Lake diamond potential should be excellent. The only xenoliths yielding data implying a greater depth of origin come from one sample from Bizzarro and Stevenson (2003) sourced close to Garnet Lake and two samples from Sand et al. (2008, this volume) from Majuagaa kimberlite near the settlement of Maniitsoq approx. $150 \mathrm{~km}$ south of Garnet Lake.

\section{Summary and Conclusions}

The Garnet Lake m.s. is one of the deepest sourced kimberlitic bodies known from West Greenland and provides mantle material from well within the diamond stability field. Associated mineral compositions reflect this deep source and are consistent with the relatively large abundance of diamonds recovered from Garnet Lake compared to elsewhere in Greenland. Thermobarometry demonstrates that the mantle lithosphere below Garnet Lake at the time of sampling in the late Neoproterozoic was relatively cool, with a $41 \mathrm{mWm}^{-2}$ mantle geotherm and deep, having a minimum depth of approx. $200 \mathrm{~km}$. The mantle was typically harzburgitic but with some eclogitic rocks present. Diamond formation appears to have been triggered by mantle metasomatism at the base of the mantle lithosphere evidenced also by associated lherzolitic garnet compositions. The pace of diamond growth largely increased over the 56 m.y. period leading up to the eventual emplacement of carbonatite, and associated kimberlite and ultramafic lamprophyre melts which transported the diamonds and other mantle material towards the surface.

\section{Acknowledgements}

Hudson Resources Inc. are gratefully acknowledged for sample provision and permission to publish and David Fisher of the Diamond Trading Company Research Centre for spectral deconvolution software. Berit Wenzel is thanked for microprobe assistance and Maya Kopylova and Thomas Stachel for FTIR provision. MH benefited from funding through GEUS and the European Community's 6th Framework Program, Marie Curie EIF Fellowships.

\section{References}

References are provided in this volume in 9th Int. Kimberlite Conf. Extended Abstract No. 9IKC-A-00183. 